\title{
Groundwater Flow Modeling at Sejorong Watershed, Sumbawa, West Nusa Tenggara, Indonesia
}

\author{
Adelide Asriati Sekar Rianda, Doni Prakasa Eka Putra, and Wahyu Wilopo \\ Department of Geological Engineering, Faculty of Engineering, Universitas Gadjah Mada, Yogyakarta, Indonesia
}

\begin{abstract}
Batu Hijau mine pit is known as one of the largest copper pit mine in Nusa Tenggara Barat, Indonesia. Similiar as other copper mine pits in Indonesia, This site also faces acid mine water (AMD) problem. Based on the mine management plan, the AMD generated from this pit is being collected into Santong ponds in the southwest of the pit located in the upstrean area if Sejorong watershed. By the next decade, Batu Hijau mine will be in the closure mine period and it is important to understand the probable movement of AMD under the Santong ponds whether the AMD leaked to groundwater or not. This research aims to develop a numerical model of groundwater flow and predict the movement of AMD by applying particle tracking method. Secondary and primary data of geology, hydrology, and hydrogeology. Also, groundwater pumpage discharge information was collected and analysed to develop hydrogeological conceptual model and the numerical model. The conceptual model of hydrogeological system in the research area is known to be built on unconfined aquifer system from a combination of weathered and fractured volcanic rocks in the upstream to middle part of watershed and majorly by alluvial and coastal deposits in the downstream area. The thickness of aquifer is vary between 20 to about $300 \mathrm{~m}$ and divide into 5 layers in the numerical model, with hydraulic conductivity ranges between 5 to $100 \mathrm{~m} /$ day and groundwater recharge is vary between 180 to $700 \mathrm{~mm}$ /year from downstream to upstream of watershed. Groundwater flow boundaries in the Sejorong watershed are mainly controlled by topographical feature as water divide boundaries and the existing of Sejorong parennial rivers in the middle of this watershed. Steady state particle tracking results from the numerical groundwater flow model show AMD from Santong ponds may migrate in groundwater only to a distance of about 500 $\mathrm{m}$ to the downstream and therefore it is unlikely that AMD seepages from Santong pond may contaminate water in the production wells.
\end{abstract}

Keywords: Acid mine water · Batu Hijau · Sejorong · Groundwater model.

\section{INTRODUCTION}

Batu Hijau copper-gold mine, Sumbawa, West Nusa Tenggara is recently a mine owned by PT Amman Mineral Nusa Tenggara (AMNT) which previously known as PT. Newmont Nusa Tenggara (NNT), see Figure 1. This mining area is located on two watershed area named Sejorong and Tongoloka watershed. In the past

\footnotetext{
${ }^{*}$ Corresponding author: D.P.E. PutrA, Department of Geological Engineering, Universitas Gadjah Mada. Jl. Grafika 2 Yogyakarta, Indonesia. E-mail: putra_dpe@ugm.ac.id
}

few years, the Batu Hijau Mine faces problem of mine acid water. According to Lembaga Fakultas Teknik UGM (LKFT) (2012), acid mine drainage has been detected in monitoring wells located at a distance of $2 \mathrm{~km}$ from the main pit center located in the Sejorong Watershed, exactly below Santong pond and it is not impossible that the distribution will increasingly extends in the near future. Awareness due to this problem increase as in the Sejorong watershed there are production wells used by PT AMNT's mining activities but also distributed 
to the community live around the mine area. Acid mine water (AMD) movement to the production wells may harm a lot of people.

In the next decade, Batu Hijau mine will be in the closure mine period, and the question arises about is it possible AMD reach the to production wells, if yes, how long the time needed for the AMD to reach these production wells. The objective of this research are to answer those questions by conducting particle-tracking simulation on a groundwater flow model. Particletracking techniques have been used for many cases of groundwater mass movement, such as lake plume transportation model (Fienen et al., 2009; Hunt et al., 2006), simulation of tritium concentration (Gusyev et al., 2014), and simulation ratios of mixing contaminant in groundwater (Cousquer et al., 2017). Besides that, particle tracking methods also used for prediction of travel time between lake and well (Pint et al., 2003) and tritium transit time in river water (Gusyev et al., 2014). Gusyev et al. (2014) have been also compared the particle-tracking techniques to advective-dispersive transport models and found very similar result between particle tracking and solute transport models.

\section{Regional GeOlogy And HydrogeOl- OGY}

As shown on Figure 1, the Sejorong Watershed is located on the west side of Sumbawa Island with area of about $70 \mathrm{~km}^{2}$. In the middle of this watershed, Sejorong River flows from northeast to west south. This river ends at Hindia Ocean. Based on the geomorphology, the Sejorong watershed is divided into several units, namely intrusion hills, structural hills, and alluvial plain units (AMNT, 2018). Intrusion hilly units are located in the western part of the model area and are composed of intrusive rocks. This unit covers $18.8 \%$ of the Sejorong watershed and has an elevation of $100 \mathrm{~m}$ to $650 \mathrm{~m}$ above sea level. The structural hilly unit covers $74 \%$ of the Sejorong watershed and has an elevation of $100 \mathrm{~m}$ to $850 \mathrm{~m}$ above sea level and the smallest geomorphological unit is an alluvial plain unit located only around the Sejorong River and the coast (Figure 2).

Geologically, the study area is composed of five lithology units: lithic and breccia tuff, ash tuff, intrusion complex, epiclastic breccia, and aluvial deposits (Figure 3). The type of aquifer that present in the research area is an unconfined aquifer developed mainly by highly weathered and fractured rocks on its relation to the geological structures, and geological structure is considered to be the cause of the presence of deep fracture zones which has high permeability (AMNT, 2018).

\section{GROUndWATER MODEL}

There are many types of groundwater model, and one of them are mathematical model which can be divided on to analytical and numerical model. Mathematically, the continuity of 3D groundwater flow is expressed in the following equation (Fetter, 2008):

$$
\begin{aligned}
S_{s} \frac{\partial h}{\partial t}= & \frac{\partial}{\partial x}\left(K_{x} \frac{\partial h}{\partial x}\right)+\frac{\partial}{\partial y}\left(K_{y} \frac{\partial h}{\partial y}\right) \\
& +\frac{\partial}{\partial z}\left(K_{z} \frac{\partial h}{\partial z}\right)
\end{aligned}
$$

Where,

$S_{s}:$ Specific storativity

$t$ : Time

$K$ : Hydraulic conductivity

$h:$ Head

On the mathematical model, Darcy's law, continuity equations, boundaries, and initial conditions together build a mathematical framework to solve problems related to hydraulic pressure and flow velocity as a function of location and time. There are three important data input for the groundwater model, which are physical framework, hydrogeology boundaries and water chemical boundaries (Bear and Cheng, 2010). Detailed of data input for groundwater flow model is shown on Table 1.

In the complexity of problem, numerical model allow analysis of groundwater flow solutions better than the analytical model. There are two approaches to solve numerical model, which are finite different method and finite element method. On this research, finite different method is used.

One important thing regarding the data input in the groundwater model is the estimation of groundwater recharge rate. Therefore, on this study, recharge rate is determined based on the simple water balance equation: 


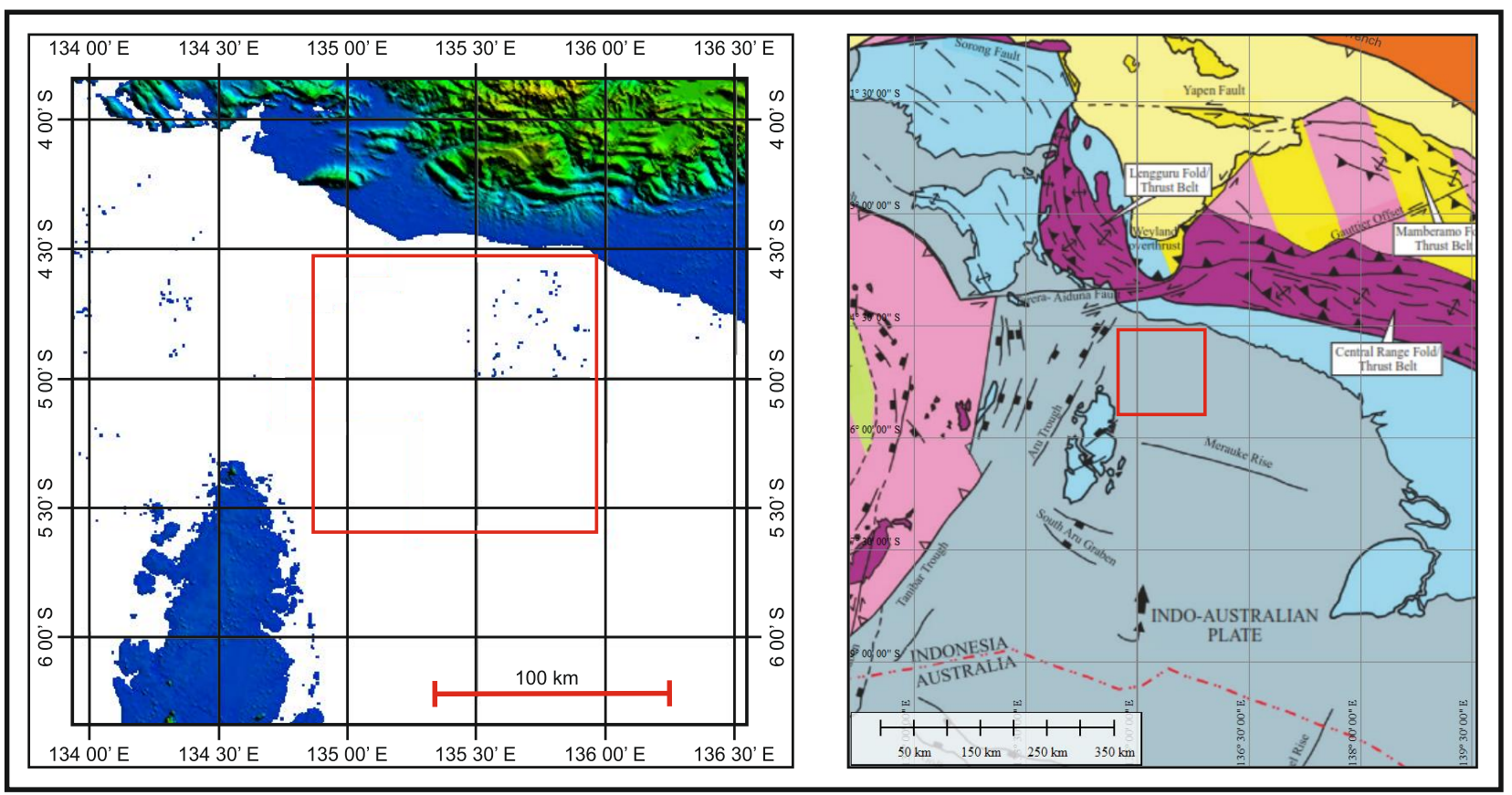

Figure 1: Study area.

Table 1: Data input for groundwater flow model (Spitz dan Moreno,1996).

\begin{tabular}{|c|c|}
\hline Data categories & Description \\
\hline Aquifer type & $\begin{array}{l}\text { Topography } \\
\text { Geology } \\
\text { Stratigraphy } \\
\text { Aquifer geometry (base, thickness,lateral distribution) } \\
\text { Lithology variety }\end{array}$ \\
\hline Aquifer characteristics & $\begin{array}{l}\text { Hydrolic conductivity } \\
\text { Porosity } \\
\text { Conductivity/ pore pressure } \\
\text { Saturation/ pore pressure } \\
\text { Specific yield } \\
\text { Specific storage }\end{array}$ \\
\hline Aquifer boundaries & $\begin{array}{l}\text { Location } \\
\text { Head } \\
\text { Flow } \\
\text { Semipermeable boundaries (leaked factor) }\end{array}$ \\
\hline Internal flow & $\begin{array}{l}\text { Recharge/discharge (area, velocity, duration) } \\
\text { Pumping and injection wells (area, velocity, duration) } \\
\text { Surface water mixing (surface water elevation, surface water based, } \\
\text { leaked factor) }\end{array}$ \\
\hline
\end{tabular}




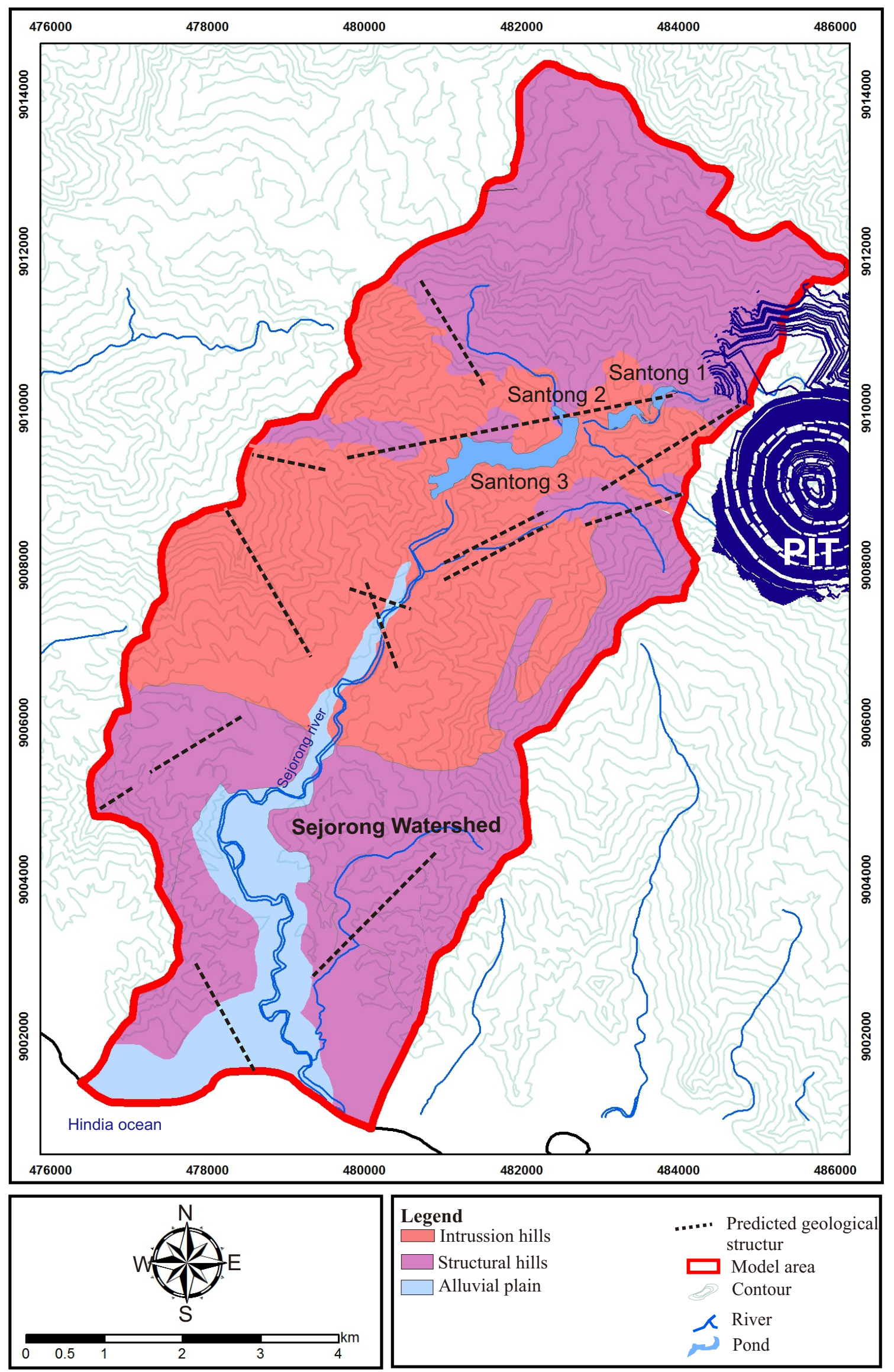

Figure 2: Geomorphological map of Sejorong watershed (AMNT, 2018). 


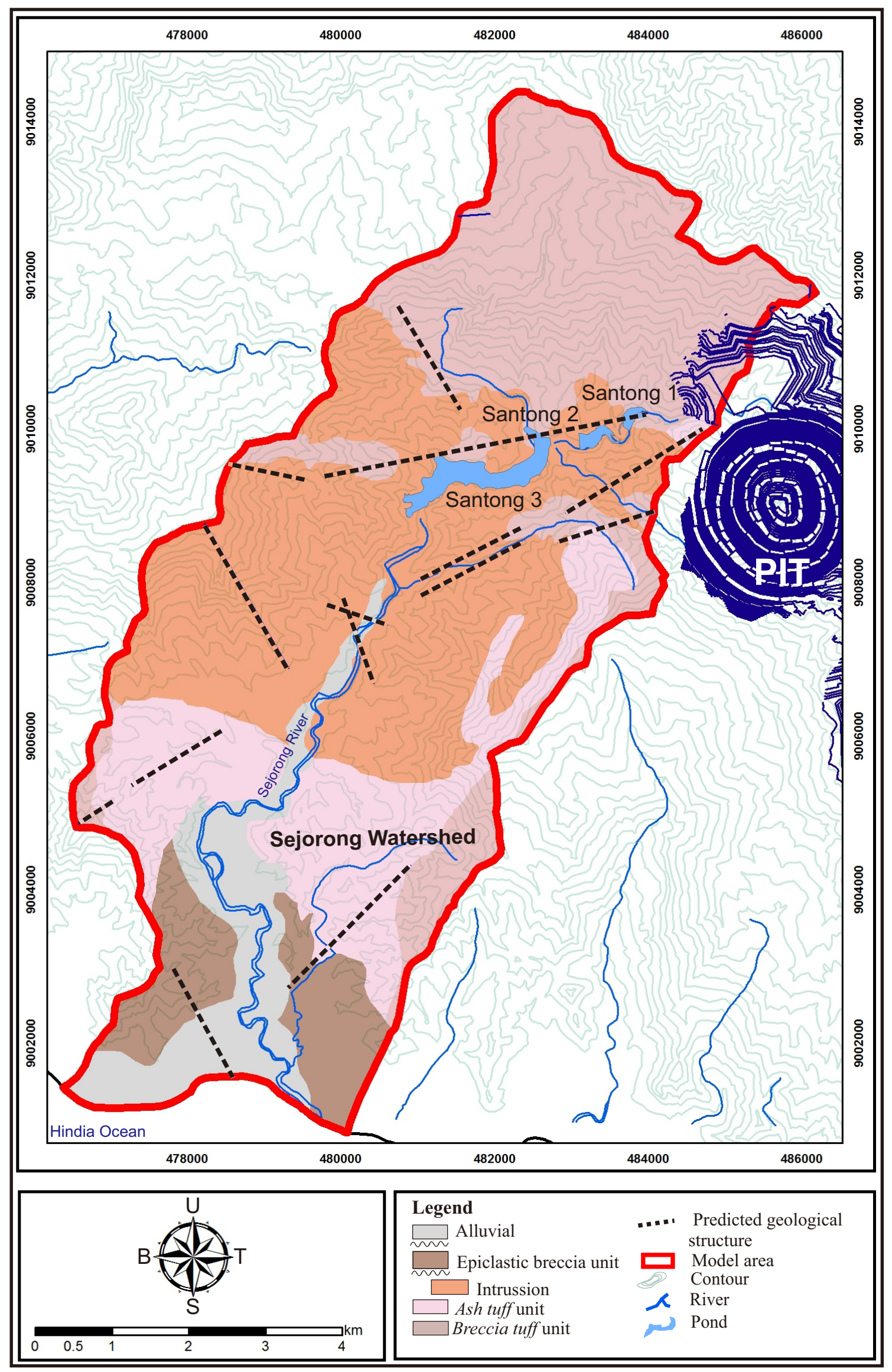

Figure 3: Geological map of Sejorong Watershed (AMNT, 2018). 


$$
\text { Recharge }=P-E T_{r}-R_{o}
$$

Where,

$P$ : Precipitation (mm/year)

$E T_{r}$ : Real evapotranspiration (mm/year)

$R_{o}:$ Runoff (mm/year)

Evapotranspiration is estimated based on the Turc (1954) equation (Putra et al. 2013), as below:

$$
E T_{r}=\frac{P}{\sqrt{0.9+\frac{P^{2}}{\left(300+25 \cdot T_{m}+0.05 \cdot T_{m}^{3}\right)^{2}}}}
$$

Where,

$E T_{r}$ : Evapotranspiration (mm/year)

$P$ : 10-year average rainfall $(\mathrm{mm} /$ year $)$

$T_{m}:$ Temperature $\left({ }^{\circ} \mathrm{C}\right)$

and runoff is calculated based on the formula below (Putra et al., 2013):

$$
R_{o}=\frac{1.411 \times p^{1.44}}{T_{m}^{1.34} \times A^{0.0613}}
$$

Where,

$$
\begin{aligned}
& R_{o}: \text { Runoff }(\mathrm{cm} / \text { year }) \\
& A: \text { Area }\left(\mathrm{km}^{2}\right) \\
& T_{m}: \text { Temperature }\left({ }^{\circ} \mathrm{C}\right)
\end{aligned}
$$

\section{Methodology}

In order to achieve the objectives, research is started by activities to collect necessary input data for build the numerical groundwater model includes the primary and secondary data. Data collection are conducted in the study area from December 2018 to February 2019. Secondary data collected were in the form of topographical data including digital elevation model (DEM) and elevation contour data, geological and morphological maps, hydrogeology map, groundwater monitoring level data and maps, borehole log and aquifer characteristics data and hidro-climatology also discharge rate of production wells data owned by PT. AMNT. Beside those secondary data, a campaign of surface water measurement were also conducted.

The list of data collected and used on this study can be seen in Table 2 and the location of data distribution can be seen on Figure 4. After data is collected, evaluation is done to understand the natural groundwater system including flow and water balance and followed by the development of the conceptual groundwater model, discretization of finite differene model area, inputing parameter, running model, model calibration and then finally conduct particle tracking model on calibrated groundwater flow model. All of this activity was conducted by using Visual Modflow software, and the important assumptions lying for this model are: (1) the surface elevation used in groundwater modeling is the result of DEM analysis and is considered to be in accordance with the original conditions in the field, (2) the value of hydraulic conductivity of each aquifer unit modeled is considered homogeneous and isotropic in all directions, and (3) the geometry of aquifer is formed by extrapolating and interpolating data and its considered correct.

\section{Results AND Discussion}

\subsection{Natural groundwater system}

Based on groundwater level data from 21 monitoring wells, a recent groundwater elevation contour map is developed (Figure 5). According to Figure 5, it is clear that regional groundwater flow on this watershed, flow to the direction of Sejorong river and ridges of catchment area act as groundwater divide boundaries. This condition govern that the groundwater source of production wells are commonly from the northwest - west and northeast - east mountain ridges and not mainly comes from Santong pond area in the north. The hydraulic head on this regional groundwater flow range between 0.2 on the upstream to 0.03 on the downstream.

According to 10 year data of rainfall, the annual average rainfall data in the study area ranges from 1800 to $2800 \mathrm{~mm} /$ year. Furthermore, the average of air temperature in the study area is about $22{ }^{\circ} \mathrm{C}$. By applying Equation 2 to Equation 4, the recharge rate on the study area can be estimated to be range from 180 to almost $700 \mathrm{~mm} /$ year (see Figure 6). The highest recharge rate is located on the northern part of the study area.

Hydrogeological conceptual model applied on this research is developed based on the hydrogeological model from the previous studies (Golder Associate (1999), Lorax-Schlumberger (2014), and LKFT UGM (2017)). According 
Table 2: Data collected and used for groundwater model in the study area.

\begin{tabular}{|c|l|l|}
\hline No. & \multicolumn{1}{|c|}{ Data } & \multicolumn{1}{|c|}{ Description } \\
\hline 1. & Topographical map of Sejorong Watershed & scale 1:50.000 \\
\hline 2. & $\begin{array}{l}\text { Regional geomorphological map of Sejorong } \\
\text { Watershed }\end{array}$ & scale 1:50.000 \\
\hline 3. & $\begin{array}{l}\text { Regional geological map of Sejorong } \\
\text { Watershed }\end{array}$ & scale 1:50.000 \\
\hline 4. & Hydrogeological map of Sejorong Watershed & scale 1:50.000 \\
\hline 5. & Contour data & .shp format \\
\hline 6. & Digital Elevation Model (DEM) & scale 1:50.000 \\
\hline 7. & Borehole Log Data incl. aquifer characteristics & 6 borehole \\
\hline 8. & Groundwater level & 21 monitoring wells \\
\hline 9. & Rainfall and Climatological Data (RS) & 4 rainfall stations (2006 to 2016) \\
\hline 10. & Surface water level & 31 points (2019) \\
\hline 11. & Pumping discharge & $\begin{array}{l}\text { 7 production wells (each about 1137 } \\
\text { L/day) }\end{array}$ \\
\hline
\end{tabular}

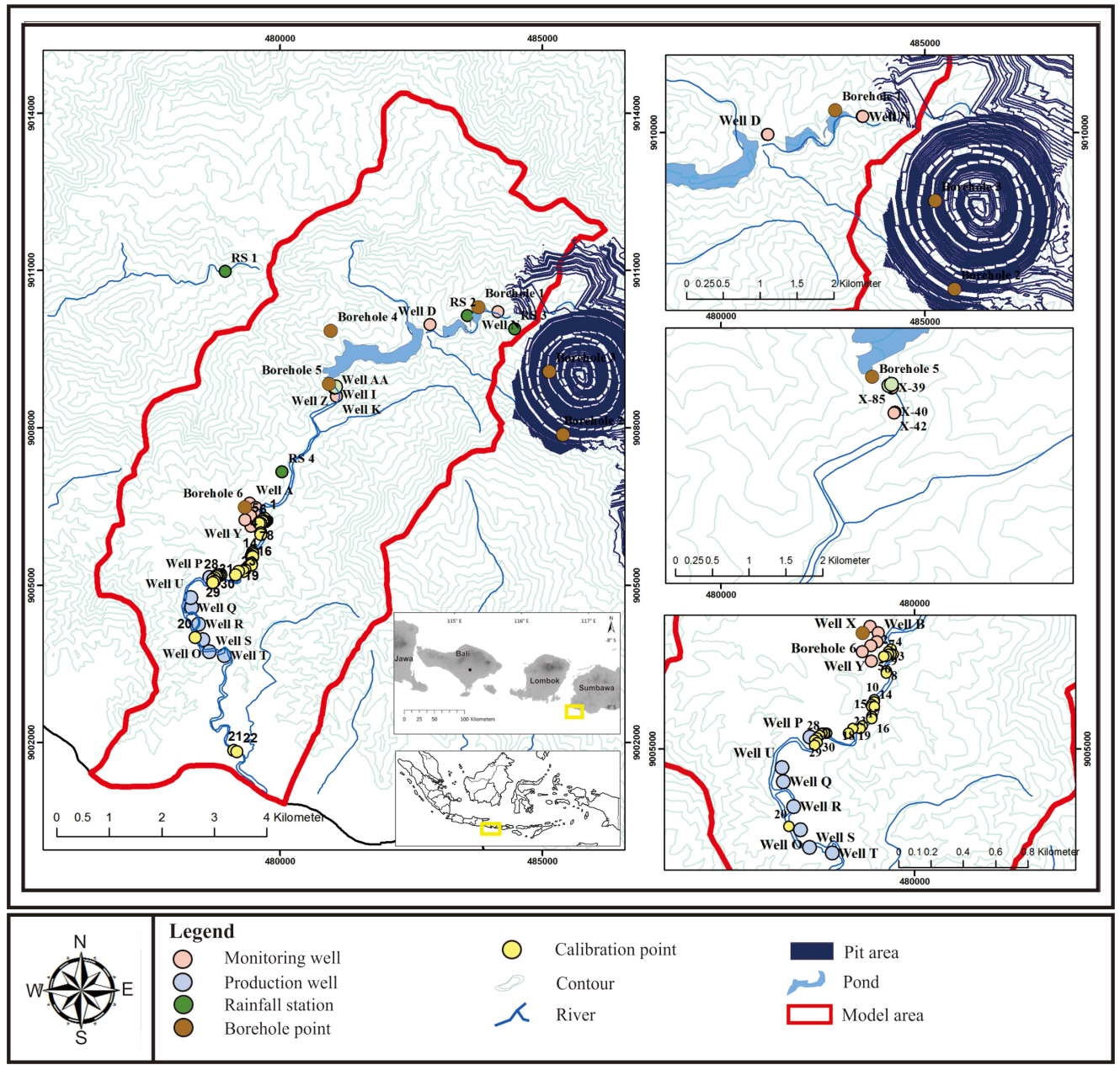

Figure 4: Distribution of data location in the study area. 


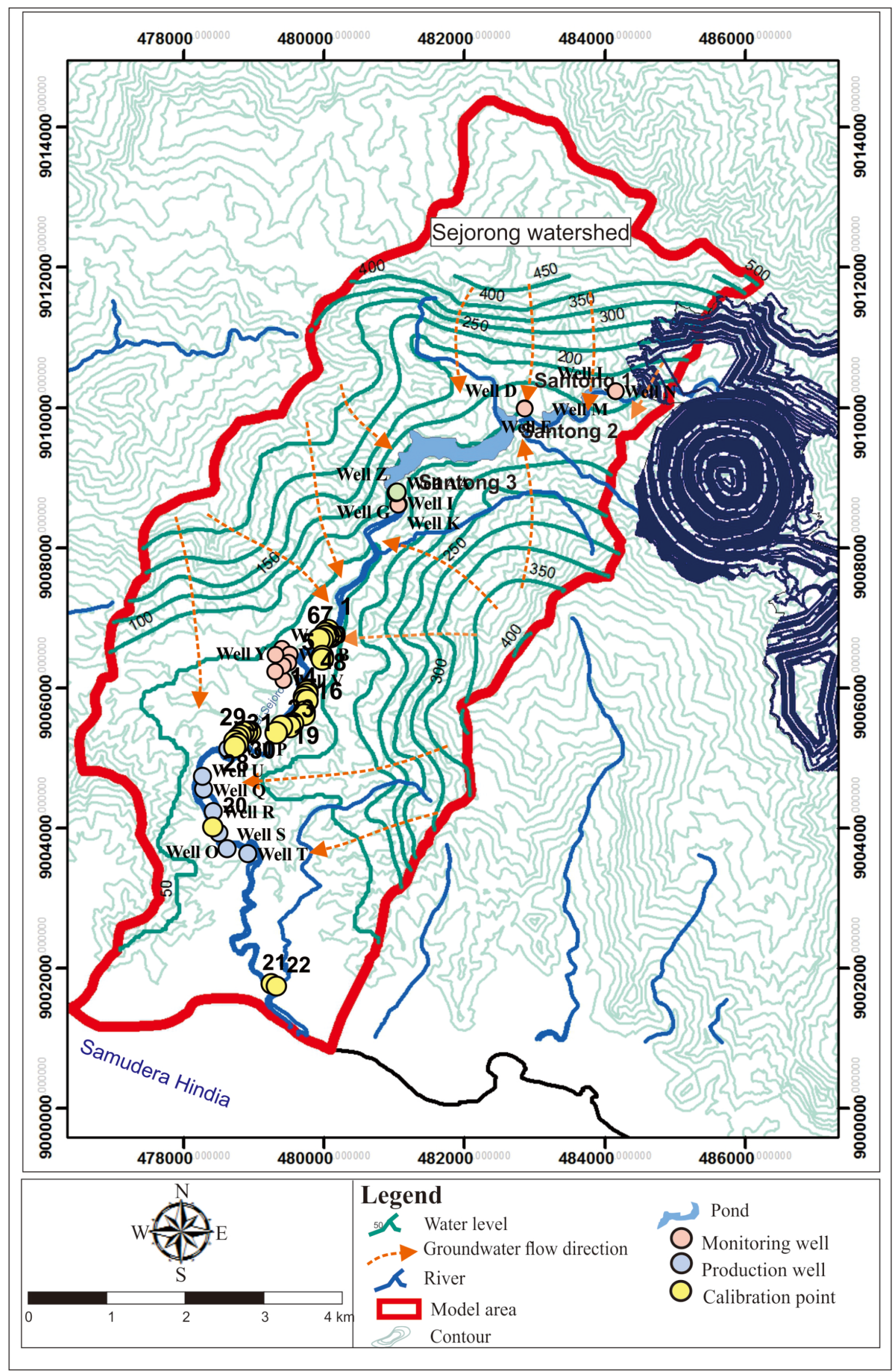

Figure 5: Observed groundwater level in the Sejorong watershed . 


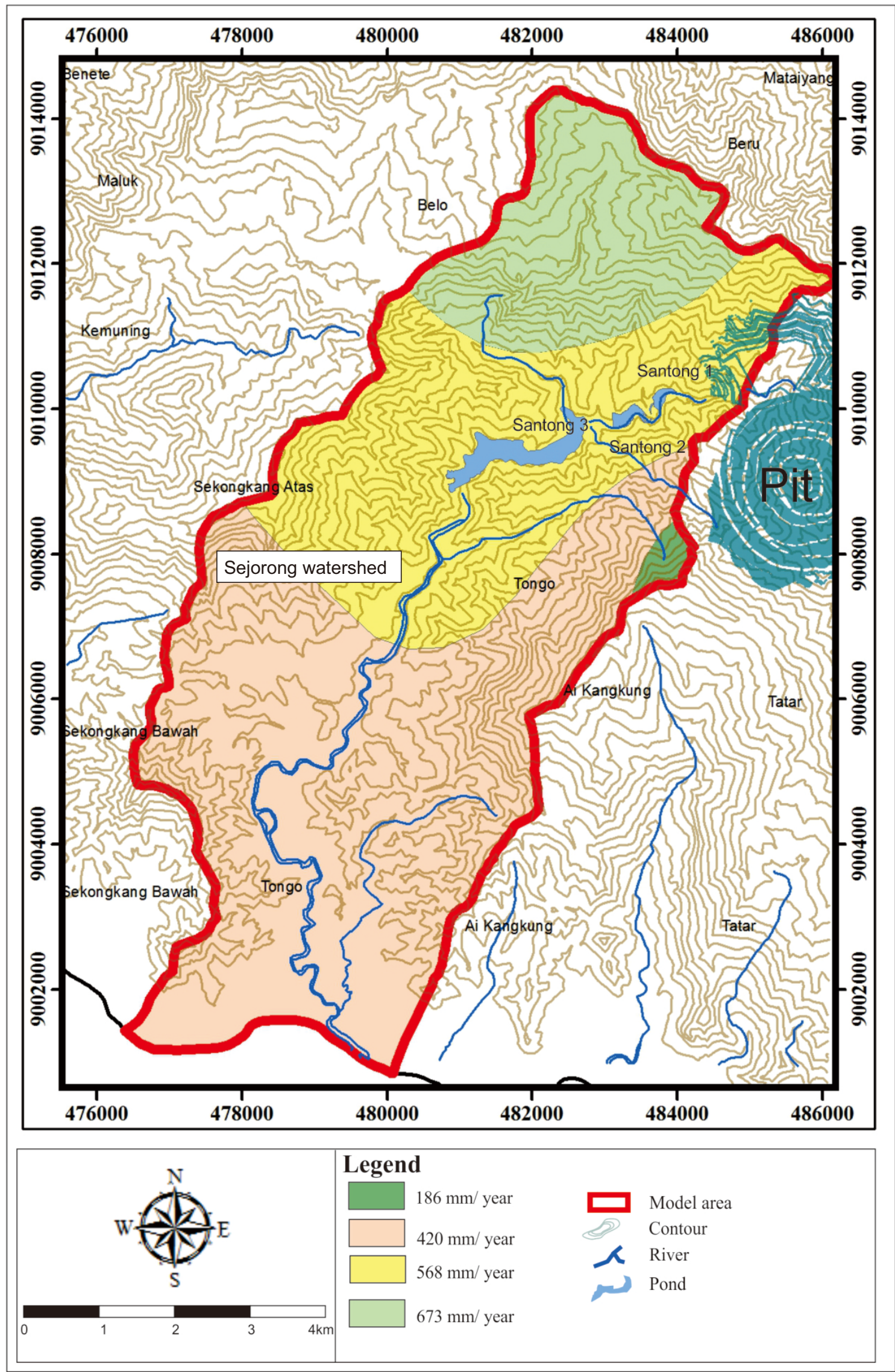

Figure 6: Groundwater recharge-rate map of Sejorong watershed. 
to those conceptual model, the unconfined groundwater system in the study area is divided into three vertically zones; (1) high permeable zone, (2) semi-permeable zone, and (3) impermeable zone. However, the thickness and the lateral extent of each zones is vary depending on the existing of lithological type and their geological structure. The thickness of aquifer vary between $20 \mathrm{~m}$ in the alluvial deposits and about $300 \mathrm{~m}$ in the volcanic rocks area. This Interpretation of the vertical and lateral distribution of the zones can be seen in Figure 7. The value of hydraulic conductivity for each aquifer unit were gathered from previous study of LKFT UGM (2012). However, data reported by LKFT UGM (2012) are $K$-value for aquifer in the epiclastic breccia and alluvial deposit generated from pumping test conducted by PT. Newmont Nusa Tenggara on several wells in the study area, however there are no information of $\mathrm{K}$-value for other unit of aquifers, therefore reference K-value from literature report are also used (see Table 3).

\subsection{Model set up}

As mentioned before, the total area of Sejorong Watershed is about $70 \mathrm{~km}^{2}$. Finite difference discretization divided this area into $50 \mathrm{~m} \times$ $50 \mathrm{~m}$ grid and differentiated into 5 vertical layers system with total thickness achieve to $500 \mathrm{~m}$ below surface on some fault affected zone (see Figure 8). On this model, the distribution of $K$ value is following the lithology zone and the boundary conditions used are as follows:

a. No flow boundaries No flow boundaries are applied at the impermeable layer and ridges of watershed boundaries.

b. Drain boundaries Drain boundaries are applied to Sejorong River as it collects groundwater from aquifers.

c. Constant head boundaries The constant head boundaries condition is applied to the Hindia Ocean in the southern part of the study area and also Santong pond.

\subsection{Model calibration}

Model calibration is conducted by changing the parameters of the model to match between observed and calculated head/water table elevation. Thirtyone calibration points were used, and the calibrated model was found after changing $\mathrm{k}$-value parameter as shown on Table 4. Figure 9 shows the standard error of $0.584 \mathrm{~m}$, Normalized RMS of $7.628 \%$ and correlation coefficient of 0.931 . These value prove that the calibrated model are fit to the observed groundwater flow condition and therefore can be used for particle tracking simulation.

\subsection{Model application}

On the particle tracking analysis, simulation is done by entering particles at the production wells to see possible path of contaminants that can enter to the production wells. This scenario was running with backward mode for particles in the production wells and forward mode for particles in the Santong pond. Particle tracking analysis is carried out with a steady state simulation. Figure 10 shows the results of particle tracking analysis, and it can be seen that the source of water of the production wells are mainly located from the aquifer of northwest side the mountain ridges and from the surrounding area in the radius of 0.5 to $4.5 \mathrm{~km}$. On other side, the particles which put on the Santong pond migrate in the groundwater only about $500 \mathrm{~m}$ from the vicinity of the Santong pond. The result of simulation reveals it may be not possible AMD from Santong pond migrate via groundwater system up to the production wells area's.

Despite the particle tracking analysis show a positive forecast, looking on the groundwater flow pattern on its relation to Sejorong river, it is wise also to bear on mind that there is still possibility AMD to contaminate the production wells. As Sejorong river is the gaining stream type, all the groundwater flow upstream will be inflow to Sejorong river. Thus, if Sejorong river contaminated by AMD (ex.overflow of Santong pond), abstraction in the production wells may pumped also water from Sejorong river and led to AMD contamination of produce water. This scenario is highly probable as groundwater system in the production wells area built by thin alluvial deposit which connected to Sejorong river. Therefore, it is necessary to upgrade the model to be include AMD mass transport simulation in the groundwater system. 


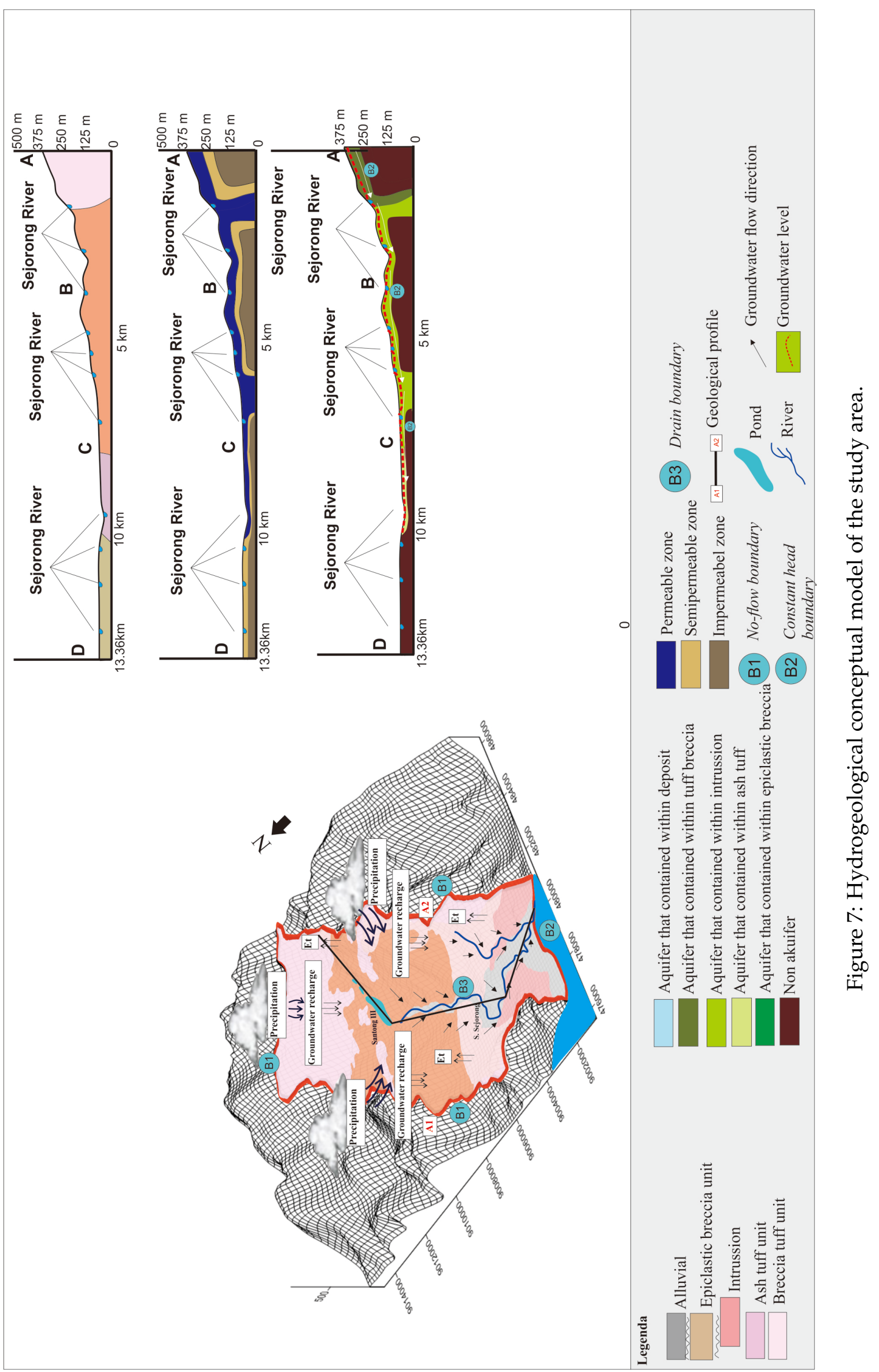



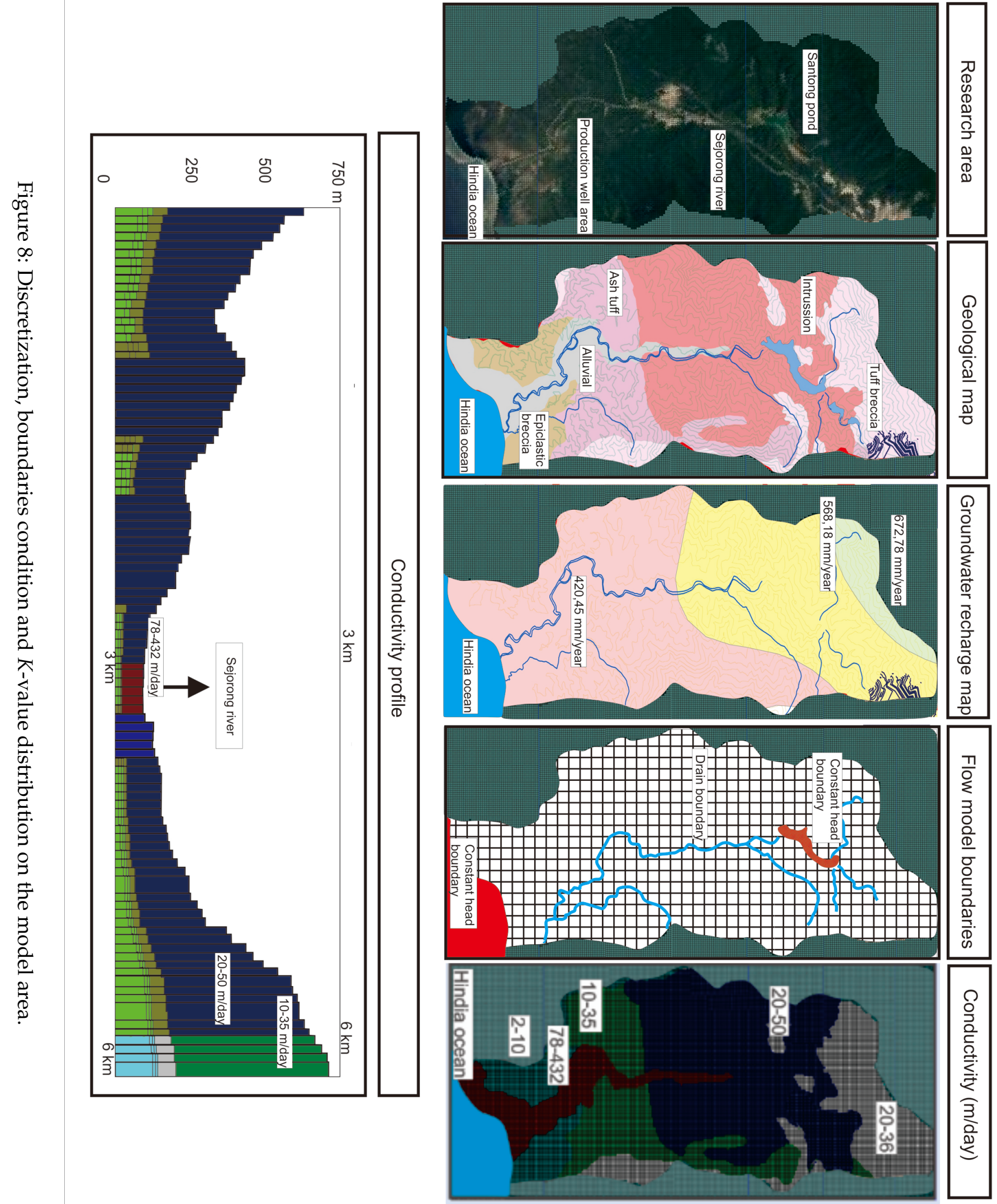
Table 3: Hydraulic conductivity of aquifer in the study area.

\begin{tabular}{|l|c|l|}
\hline \multicolumn{1}{|c|}{ Aquifer } & K values (m/day) & \multicolumn{1}{c|}{ References } \\
\hline $\begin{array}{l}\text { Aquifer tuff breccia (weathered and geological } \\
\text { structure affected) }\end{array}$ & $20-36$ & Geldon,2004 \\
\hline $\begin{array}{l}\text { Aquifer - igneous intrusion (weathered and } \\
\text { geological structure affected) }\end{array}$ & $20-50$ & Spitz \& Moreno, 1996 \\
\hline $\begin{array}{l}\text { Aquifer - ash tuff (weathered and geological } \\
\text { structure affected) }\end{array}$ & $10-35$ & Spitz \& Moreno, 1996 \\
\hline $\begin{array}{l}\text { Aquifer - epiclastic breccia (weathered and } \\
\text { geological structure affected) }\end{array}$ & $2-10$ & LKFT (2012) \\
\hline Aquifer- alluvial deposit & $78-432$ & LKFT (2012) \\
\hline
\end{tabular}

Table 4: Hydraulic conductivity value of each aquifer on calibrated model.

\begin{tabular}{|l|c|}
\hline \multicolumn{1}{|c|}{ Aquifer } & $\begin{array}{l}\text { Kvalues } \\
\text { (m/day) }\end{array}$ \\
\hline $\begin{array}{l}\text { Aquifer tuff breccia (weathered } \\
\text { and geological structure } \\
\text { affected) }\end{array}$ & 28 \\
\hline $\begin{array}{l}\text { Aquifer - igneous intrusion } \\
\text { (weathered and geological } \\
\text { structure affected) }\end{array}$ & 41 \\
\hline $\begin{array}{l}\text { Aquifer - ash tuff (weathered } \\
\text { and geological structure } \\
\text { affected) }\end{array}$ & 20 \\
\hline $\begin{array}{l}\text { Aquifer - epiclastic breccia } \\
\text { (weathered and geological } \\
\text { structure affected) }\end{array}$ & 5 \\
\hline Aquifer- alluvial deposit & 100 \\
\hline
\end{tabular}

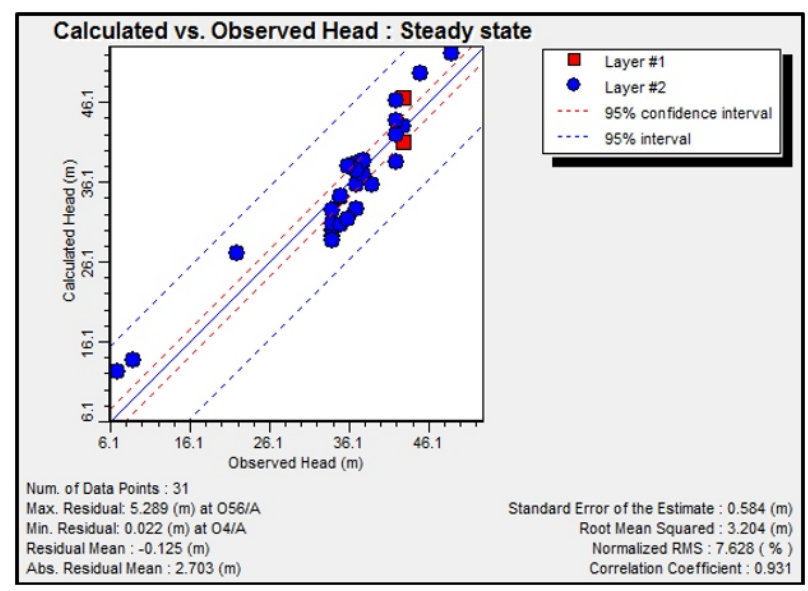

Figure 9: Calibration chart of the final model.

\section{CONCLUSION}

According to the result and discussion, there are some conclusion can be taken on this research, which are:

a. The groundwater on the Sejorong watershed flow to the direction of Sejorong river and ended on the Hindia ocean, and ridges of Sejorong catchment area act as groundwater divide boundaries. The aquifer system on this area has thickness from 20 to about $300 \mathrm{~m}$, hydraulic conductivities range from 5 to $100 \mathrm{~m} /$ day and hydraulic head range from 0.2 to 0.03 , with groundwater velocities are ranges from 0.15 to $20 \mathrm{~m} /$ day.

b. The groundwater recharge on the Sejorong watershed is about 180 to $700 \mathrm{~mm} /$ year, due to its high yearly rainfall which may up to $2800 \mathrm{~mm} /$ year.

c. Result from particle tracking analysis show that it is not possible AMD seepages of Santong pond can migrate in the groundwater system to the production wells area.

d. The risk of contamination of the production wells by AMD can be increase if Sejorong river is contaminated by AMD, therefore a mitigation plan to avoid pollution or contamination of AMD to Sejorong river is necessary.

\section{ACKNOWLEDGEMENTS}

The authors are grateful to Jorina Waworuntu Ph.D and Rissa Anungstri for data and research opportunity at Amman Mineral Nusa Tenggara 


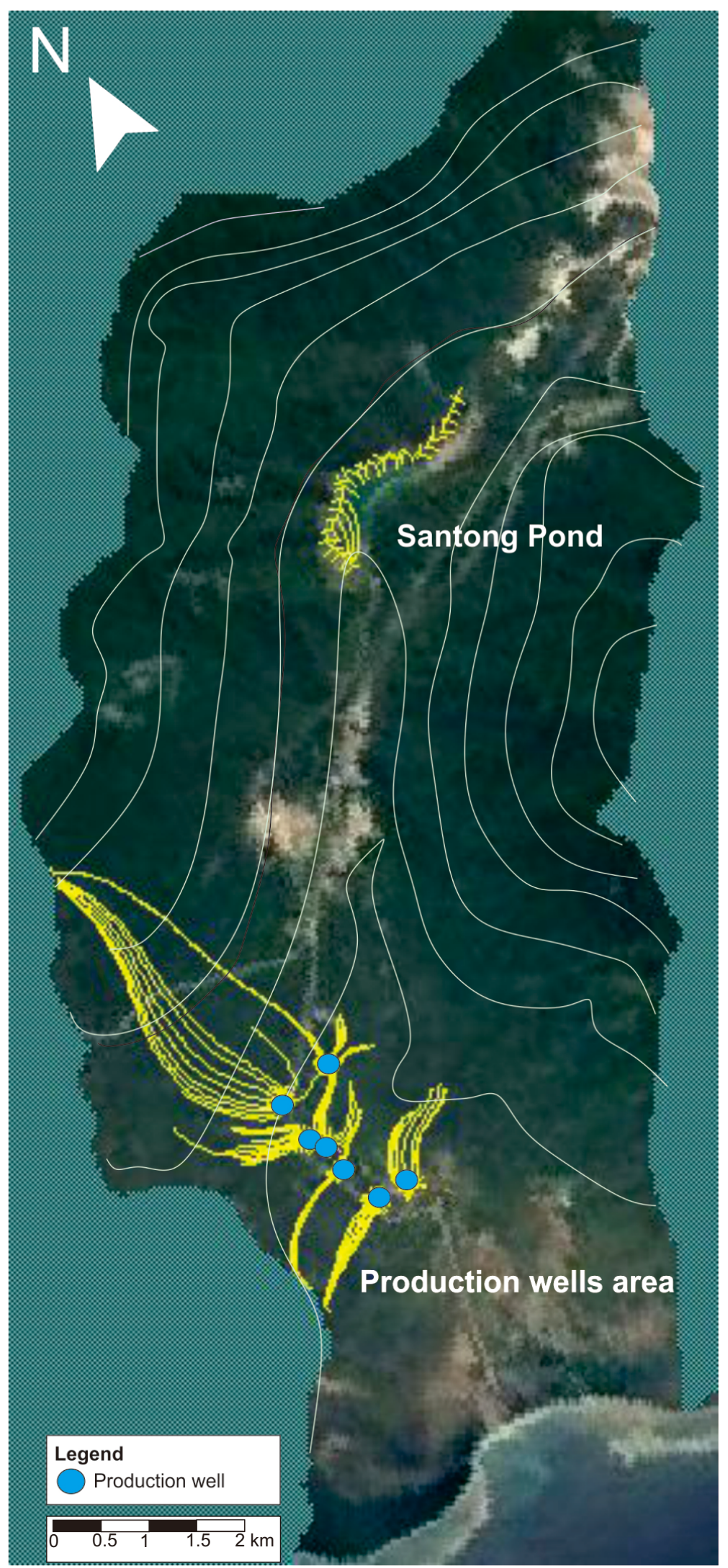

Figure 10: Calibrated groundwater flow and particles tracking analysis in the study area. 
mining area. The authors also appreciate the support provided by Department of Geological Engineering, Faculty of Engineering, Universitas Gadjah Mada to grant scholarship for the first author and fund for this research.

\section{REFERENCES}

AMNT (2018) Groundwater Archive Data, PT Amman Mineral Nusa Tenggara (unpublished report).

Bear, J. and Cheng, A.H.D. (2010) Modeling Groundwater Flow and Contaminant Transport. New York: Springer Science + Business Media B.V. 756p.

Cousquer, Y., Pryet, A., Flipo, N., Delbart, C., and Dupuy, A. (2017) Estimating River Conductance From Prior Information To Improve Surface-Subsurface Model Calibration. Ground water, Volume 55, Issue 3, p. 408-418.

Fetter, C.W. (2008), Contaminant Hydrogeology, $2^{\text {nd }}$ Edition, Waveland Press, Inc., $500 \mathrm{p}$.

Fienen, M., Hunt, R., Krabbenhoft, D., and Clemo, T. (2009) Obtaining Parsimonious Hydraulic Conductivity Felds using Head and Transport Observations: a Bayesian Geostatistical parameter estimation approach. Water Resources Research, Volume 45, Issue 8, W08405.

Geldon, A.L. (2004) Hydraulic Tests of Miocene Volcanic Rocks at Yucca Mountain and Pahute Mesa and Implications for Groundwater Flow in the Southwest Nevada Volcanic Field, Nevada and California. Geological Society of America Special Paper 381, 93p.

Golder Associates (1999) Batu Hijau Project, Indonesia: Waste Dump Management Plan: Volume 3 - Hydrogeology. Lombok: Unpublished (Newmont Nusa Tenggara Company Final Report).
Gusyev, M., Abrams, D., Toews, M., Morgenstern, U., and Stewart, M. (2014) A Comparison Of Particle-Tracking And Solute Transport Methods For Simulation Of Tritium Concentrations And Groundwater Transit Times In River Water. Hydrology and Earth System Sciences, 18, p.31093119.

Hunt, R.J., Feinstein, D.T., Pint, C.D., and Anderson, M.P. (2006) The Importance Of Diverse Data Types To Calibrate A Watershed Model Of The Trout Lake Basin, Northern Wisconsin, Jurnal Hydrology 321, p. 286-296

LKFT UGM (2012) Kajian Hidrogeologi Komprehensif Daerah Pertambangan Batu Hijau, Kabupaten Sumbawa Barat, Provinsi Nusa Tenggara Barat. Lombok: PT Newmont Nusa Tenggara. (unpublished report).

LKFT UGM (2017) Kajian Hidrogeologi Komprehensif dan Kajian air Tanah di Masyarakat di sekitar Daerah Pertambangan Batu Hijau, Lombok: PT Newmont Nusa Tenggara (unpublished report).

Lorax-Schlumberger (2014) Hydrogeological Assessment of the Batu Hijau Mine and Implications for Closure Detailed Report. Lombok: PT Newmont Nusa Tenggara (unpublished report).

Pint, C.D., Hunt, R.J., Anderson, M.P. (2003) Flowpath delineation and ground water age, Allequash Basin, Wisconsin. Groundwater, Volume 41, No.7, p. 895-902.

Putra, D.P.E., Iqbal, M., Hendrayana, H., and Putranto, T.T. (2013) Assessment of Optimum Yield of Groundwater Withdrawal in the Yogyakarta City, Journal of Southeast Asian Applied Geology, Vol. 5, No.1, January-June 2013. p. 41-49.

Spitz, K. and Moreno, J. (1996) A Practical Guide to Groundwater and Solute Transport Modeling, John Wiley \& Sons, Canada. 480p. 